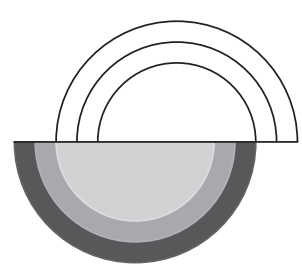

国際情報 7th International RILEM Conference on Self-Compacting Concrete/1st International Conference on Rheology and Processing of Construction Materials/67th RILEM week一参加報告

五十嵐 心 一*

\section{1. 会議の概要}

本稿タイトルのとおり第 7 回自己充填コンクリートに 関する RILEM 国際会議，第 1 回建設材料のレオロジー と製造工程に関する国際会議，そして年次恒例行事であ る第 67 回 RILEM ウィークと，3つの研究集会を兼ねた 学会が，2013 年 9 月 1 日から 4 日の日程で, フランスは パリ市内， 6 区のピエールマリーキュリー大学 (UPMC) の会議施設 Les Cordeliers で開催された。会場はパリの 5 区と 6 区にまたがるカルチェラタン地区の一角にあり, ノートルダム大聖堂やルーブル美術館も徒歩圈内で，空き 時間に観光もできる絶好のロケーションであった（図-1）。 ソルボンヌ大学や UPMC の学生が行き交う表通りから, 一歩裏の路地を入ればそこには閑静なアパルトマンがあ るという環境で，最もパリらしい地域といえそうな所で

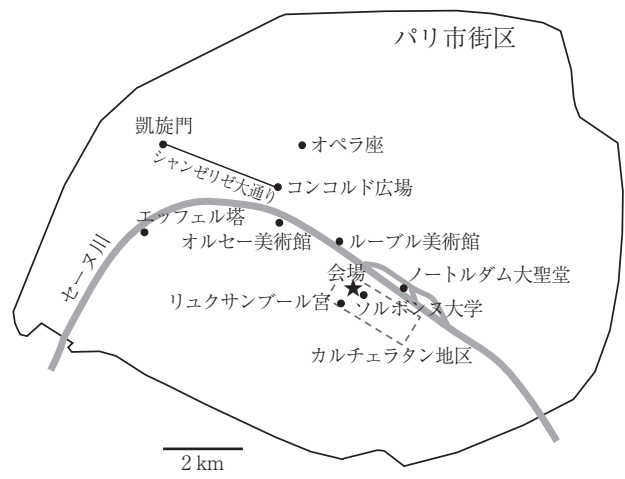

図-1＼cjkstart会場ロケーションと観光地の位置関係
あった。

配布資料によると，参加登録者数は 291 名で，地元フ ランスはもとよりヨーロッパ各国からの参加者で多数を 占めるのは当然であるが，日本からの登録者数は 6 名で あった。やや物足りない気がしないでもないが，今回の 会議のテーマと我が国の研究動向を考えると，これもむ ベなるかなという思いである。

\section{2. 会議の内容}

主催者発表によると，会議へのアブストラクト投稿は 300 件ほどあり，その中からピアレビューを経た 48 編 の論文が冊子体のプロシーディングとして発行され，そ の他の査読を経ない 160 編の論文が CD 版プロシーディ ングに収められたとのことである。

第 2 日午前の開会式では, 本会議の実行委員長である Nicolas Roussel 氏（IFSTTAR；フランス中央土木研究 所), RILEM 会長である Mark Alexander 氏（ケープタ ウン大学), そして Bruno Godard 氏（フランス土木学 会）が開会の挨拶を述べ，その後，Phillippe Coussot氏 (Laboratoire Navier（IFSTTAR を含むいくつかの研究 機関の連合体)）が「建設材料のレオロジー」と題する 基調講演を行い, 実質 3 日間の大会の幕を開けた。

3 つの会場に分かれて一般講演 15 分，基調講演や招 待講演は 30 分の割り当て時間で会議は進行していった。 3つの研究集会の発表が並行して進行していくため，プ ログラムを見て入った会場の発表が，いったいどの研究

表-1ＲILEM ウィーク招待講演一覧

\begin{tabular}{l|l|l}
\hline \multicolumn{1}{c|}{ 講演種類 } & \multicolumn{1}{c|}{ 講演者 } & \\
\hline $\begin{array}{l}\text { ロバートエルミート } \\
\text { メダル受賞講演 }\end{array}$ & John L. Provis & GEOPOLYMERS AND OTHER ALKALI ACTIVATED MATERIALS -WHY, HOW, AND WHAT? \\
\hline 委員会報告 & Z. P. Bazant & Report of TC 242-MDC (Multi-decade creep and shrinkage of concrete) \\
\hline 委員会報告 & K. H. Khayat & Report of TC 228-MPS (Mechanical properties of self-compacting concrete) \\
\hline 委員会報告 & L. Ottosen & Report of TC 229-EPE (Electrokinetic processes in civil and environmental engineering) \\
\hline 委員会報告 & C. Pellegrino & Report of TC 234-DUC (Design procedures for the use of composites in strengthening of reinforced concrete structures) \\
\hline 委員会報告 & J. Weiss & Report of TC 214-CCD (Concrete cracking and its relation to durability) \\
\hline 委員会報告 & P. Nixon & Report of TC 219-ACS (Alkali aggregate reaction in concrete structures) \\
\hline
\end{tabular}


集会に属する研究発表なのかよくわからないという感じ だった。また，欠番の講演もかなり多く，聴衆もまばら というセッションも少なからずあった。それらの空き時 間を埋めるように，途中に飛び入りの研究発表や著名な 研究者の話題提供が組み込まれていたりした。

それらの研究発表とは別に, RILEM ウィークの恒例 であるロバートエルミートメダル受賞講演と各研究委員 会（テクニカルコミティー； TC）の活動報告を行う講 演が組み达まれていた。今回の講演は表-1のとおりであ る。受賞講演がジオポリマーに関するもので，また，こ の国際会議中の発表論文にもジオポリマー関連のものが 多数あって, 建設材料分野におけるセメント代替, $\mathrm{CO}_{2}$ 削減の意識の高揚を強く印象付けられた。また，かなり 年配の著名研究者が，いまだにかくしゃくとして最先端 の研究委員会を牽引する姿勢に深く感心させられた。

\section{3. 学会の楽しみ}

RILEM ウィークに参加する大きな楽しみは，TCに参 加することである。今回も前回の開催地ケープタウンに引 き続いて TC 225-SAP の委員会がリュクサンブール宮殿 近くの Ecole des Mines で開催された。日本からは大分高 専の一宮一夫教授と筆者が出席した。この委員会は新し い材料である超吸水性ポリマー（SAP）の新たな利用法 を探ることを目的としている。これまでに，共通の材料 と配合に基づいて自己収縮抑制に関するラウンドロビン 試験を実施し，その結果を RILEM の論文誌（Mat.\& Struc., DOI 10.1617/s 11527-013-0078-5）に発表してい る。今回はラウンドロビン試験の第二弾である SAP 使用 コンクリートの耐凍害性を調べる試験の進渉状況につい て話し合われた。こういう試験に参加すると，自分のとこ ろでやったデータが他の研究機関のデータと大きく離れ ていたらどうしようと昔はヒヤヒヤしていたのだが，歳を 重ね顔見知りの委員も多くなってくると「金沢大学のデー 夕が異常ではないか？」といわれてみんなの視線を浴び ても，「ああ，そうですね。今やり直していますので」と 適当に言い訳をつけて流せるようになった。年に 1 回の 顔合わせで，これまでの経緯を把握していない委員も参 加したりするので，過去に遡っての説明があったりで，思 い出しながら会議内容をフォローできる。気軽な雑談風 に議論が進むいつもの温かい雲囲気のまま委員会は終了 し，その後皆で記念写真を撮って散会となった（写真-1）。 今回もう一つ楽しみにしていたのがバンケットであ る。パリという開催地でそれなりの参加費であったので, どんなフランス料理がと期待して出向いた。バンケット の会場はオペラ座近くのデパート, プランタン・オスマ ン本店 6 階の「ブラッスリー・プランタン」であった。 大きなステンドグラスの円天井の下に䨌囲気のいいレス トランがしつらえてあり, 多くの参加者がその美しさに 何度もシャッターを切っていた（写真-2）。筆者は宴会

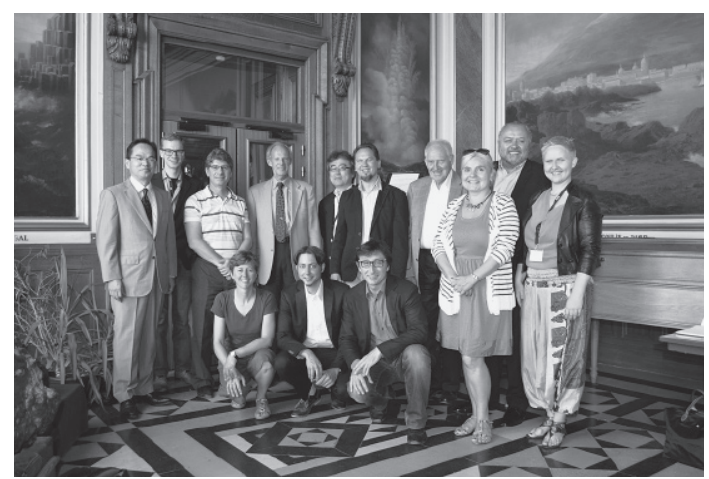

写真-1 研究委員会 TC 225-SAP 会議終了後

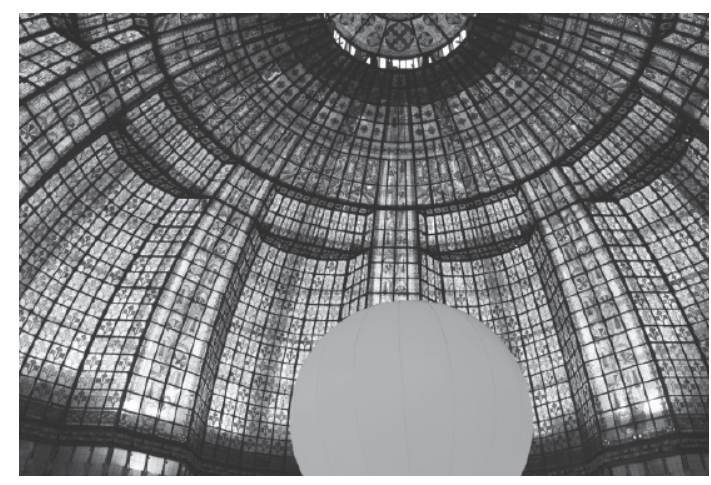

写真-2 バンケット会場中央のバルーンとステンドグラス

表-2 今後の RILEM ウィーク開催予定

\begin{tabular}{cll}
\hline 開催年 & 開催地 & 開催期間 \\
\hline 2014 & サンパウロ (ブラジル $)$ & $8 / 31 \sim 9 / 5$ \\
2015 & メルボルン (オーストラリア) & $8 / 30 \sim 9 / 2$ \\
2016 & コペンハーゲン (デンマーク) & $8 / 21 \sim 24$ \\
2017 & チェンナイ (インド $)$ & $9 / 3 \sim 6$ \\
2018 & デルフト (オランダ $)$ & $9 / 2 \sim 5$ \\
\hline
\end{tabular}

の楽しい雲囲気にのまれてワインが進んでしまい, 結 局，肝心の料理の内容を覚えていない。今どきの若い人 たちのようにすぐに携帯を出す習慣があればと, 本稿を 書いている今になって悔やんでいる。

\section{4. ま め}

13 年ぶりのパリ訪問であった。昔 NHK の人気ニュー スキャスターが世界にはぶらぶら歩きに堪える街という のがいくつかあるといい, 確かパリはその一つであった と記憶している。今回は出張前後のスケジュールの関係 で，パリを住んでいるように歩くことができ，個人的に はそのことが実感できる出張となり楽しかった。

RILEM ウィークは毎年開催地が変わり, 併催の国際会 議の内容も異なるが, 開催時期がほぼ決まっていて, スケ ジュールが立てやすい。開催地は必ずしも欧州に限らず, 今後の開催予定は表-2のとおりである。もし行ってみた い都市があったら，それを目的に学会に論文投稿すると いうのはいかがだろうか。動機としては本末転倒であろう。 でも，大きな声では言えないが，私はそうかもしれない。 